\title{
Post Harvest Corn Handling for Improving Quality and Competitiveness
}

\author{
Payung Layuk ${ }^{1, *}$, Meivie Lintang ${ }^{1}$, Yusuf $^{1}$ \\ ${ }^{1}$ The Assessment Institute for Agricultural Technology of North Sulawesi Jl. Kaharudin Nasution No. \\ 341 Pekanbaru, Riau, Indonesia
}

\begin{abstract}
The awareness and knowledge of postharvest losses at the farm level is still very low, so it is necessary to conduct research to determine the application of postharvest technology at the farm level. The research was conducted from January to December 2017 in Minahasa, North Minahasa and South Minahasa districts. The results of the study showed that each stage of postharvest treatment varied from $5 \%$ of conventional and $1.92 \%$ of introduced technology. The use of postharvest BB shelling tools with an operating time of 9 minutes $/ 100 \mathrm{~kg}$ with an operational cost of $187,800 \mathrm{IDR} / \mathrm{ha}$, results in a loss of yield of about $0.8 \%$, peeled corn sheller with an operating time of 10.25 minutes $/ 100 \mathrm{~kg}$ and an operating cost of $213,400 \mathrm{IDR} / \mathrm{ha}$ lost yield of $0.95 \%$, compared to traditional shelling tools with an operating time of 130 minutes $/ 100 \mathrm{~kg}$ and operational costs of $1,354,100 \mathrm{IDR} / \mathrm{ha}$, yield loss of $0.2 \%$ lower but high labor costs. The use of a dryer with a capacity of 3 - 4 tons with a drying time of 12-17 hours can save the labor cost of 2 working days $(200,000$ IDR) when compared to a sun dryer, the yield loss is $0.1-0.2 \%$. Dry shelled maize, rice, and corn bran stored for 3 months have not experienced a significant change in moisture content, with the control treatment, the use of zeolite, activated charcoal, quicklime, turmeric powder and fragrant lemongrass powder. The use of activated charcoal and zeolites can inhibit changes in moisture content and the growth of Sitophilus zeamais.
\end{abstract}

\section{Introduction}

Corn commodity has a very strategic role, both in the food security system and as the driving wheel of the national economy. In the next five years the demand for corn for the food, feed, and other industrial needs is projected to continue to increase along with population growth.

Indonesia's population growth rate per year is 1.49 percent and the population is projected to increase by around 3.5 million people each year. In addition, the increase in corn demand is also driven by an increase in community income which has an impact on increasing purchasing power, especially for meeting the need for chicken meat [19]. Corn demand continues to increase directly proportional to population growth, as a result of increased food needs, consumption of animal protein and energy [41].

\footnotetext{
* Corresponding author: playuk21@gmail.com
} 
Therefore, the Government is trying hard to increase its production through the expansion of planting corn through the Gema Palagung program with a target within the period $2005-2015$, there will be an additional harvest area of 456,810 ha and the Special Efforts Program [19].

The increase in corn production cannot be separated from its post-harvest activities. Post- harvest corn activities include harvesting, transportation, drying, threshing and storage [2]. The amount of losses in post-harvest corn activities (not included in storage activities) varies from $1.2-5.2 \%$ of losses due to scattered and $5-10 \%$ due to quality losses. Based on data from the Post Harvest Directorate (2013), the magnitude of the post-harvest shrinkage corn base rate is $5.20 \%$.

Harvest and drying times affect the number of corn kernels that are not suitable for human consumption, with a loss of 3.6-11.2\% [15]. The rate of loss or yield loss due to rodents worldwide is estimated to be at least 30\% [21] Furthermore; [48] yield losses by rodents of up to $35 \%$ of grain stored; It is almost similar to the conclusion drawn by [23] that rodents significantly contribute to yield losses, namely about 1.3 million tonnes of food loss each year.

The harvested area of corn in North Sulawesi Province in 2014 was 80,8127,475 ha with a production of 488,362 tons. If the post-harvest losses are $5.20 \%$, the yield loss will be 2,539 tons of corn. This figure is quite large and could reduce the self-sufficiency target for corn in North Sulawesi. This means that the post-harvest stage plays an important role in reducing yield losses. In connection with the increasing demand for maize, post-harvest handling techniques must be implemented properly, so that the maize produced is of high quality, and has an impact on a relatively high selling price [2]. The use of post-harvest equipment is a must in terms of reducing yield losses and improving quality and shortening work time [39].

Through the study post-harvest corn handling in North Sulawesi, it is expected to be able to analyze the system and process of post-harvest corn that has existed in North Sulawesi, can reduce yield losses and produce good quality corn, as well as get relatively high selling prices. The introduction of post-harvest equipment is expected to overcome labor constraints in corn farming, suppress yield loss and improve quality in order to increase corn farm income.

\section{Materials and Methods}

The assessment activities were carried out in the corn center areas in North Sulawesi, namely Minahasa, North Minahasa and South Minahasa districts. The storage study was conducted at the BPTP Laboratory. The assessment is carried out from January 2017 to December 2017.

The assessment materials are in the form of corn plants, packaging materials and other supporting materials. The equipment used were corn harvesting tools, threshing tools, dryers, dry shelled corn storage equipment and tools used in packaging and other assistive devices.

\subsection{Research stages:}

a. Secondary data collection in related institutions in the form of area, harvest, production and productivity of corn as well as the level of corn consumption and market prices

b. Primary data collection; Data is collected in the form of postharvest stages that have been carried out, the technology used, the equipment used. Data was collected at the farmer group level and the BPP level through structured interviews and questionnaire. 
For data collection yield losses on each component: harvesting, threshing, drying, storage and packaging. Data collection in the field by taking random samples and interviews. Interviews were conducted in groups and individual community members who have expertise and social status such as community leaders, and other community members who have knowledge of corn farming and corn agro-industry activities through "open ended" interview techniques.

c. Identify the needs of farming tools by paying attention to agronomic aspects: cultivation techniques, cropping patterns, climate patterns of distribution of types of activities in a year, distribution of the number of workers per hectare needed, distribution of available labor and its capacity and volume of work to be worked on. Economic aspects: investment in labor costs and materials needed. Technical aspects: type and capacity of agricultural machinery to be used, estimated rest periods, estimated service life, after sales service support, farm credit availability and other financing systems.

d. The study was conducted in one of the farmer groups that can be applied after harvesting equipment. The treatment applied was the response of the sheller and dryer to some types of corn varieties and the variation of operating time. The suitability test of agricultural machinery includes: functional test, verification, and adaptation test on a large scale so that the machineries are technically, economically and socially feasible.

e. Storage of corn kernels, corn rice and rice bran using zeolite absorbent material, Calcium oxide, activated charcoal, citronella powder and turmeric powder with a composition of $20 \%$ of the weight of the material. $1 \mathrm{~kg}$ of material is packed using 0.08 $\mathrm{mm}$ Polyethylene. The material is then stored at room temperature. Observations were made on the water content and the presence of Sitophilus zeamais beetles at 0 months, 3 and 6 months of storage.

\subsection{Data collection}

\subsubsection{Secondary data}

Secondary data collected included socio-cultural aspects of the community at the study site in general, bio-physical condition, potential yield of maize, level of knowledge about postharvest handling and the availability of agricultural machine tools.

\subsubsection{Primary Data}

a. Socio-economic and cultural data obtained from structured and semi-structural interviews. The data obtained in the form of quantitative data on socio-economic aspects: labor costs, investment, materials needed while the cultural aspects: planting, harvesting and post-harvest systems. The number of agricultural machine tools needed is calculated based on the physical volume of work available minus the volume of work that can be completed with available labor and machinery [2] with the following equation:

$$
U T=\frac{L s-L g}{C a p}
$$

$\begin{array}{ll}\text { UT } & \text { : Agricultural machine tools needed for an activity in the region } \\ \text { Ls } & \text { : Work Volume } \\ \text { Lg } & \text { : Volume of work that can be worked on by human resources } \\ \text { Cap } & \text { : Capacity per unit of agricultural machine tool needed }\end{array}$


b. Physical and biophysical data at the time of direct observation in the field (field observation): type of harvest and post-harvest equipment, type and capacity of machineries, estimated time of use, age of machineries, availability of the financing system. Technical test data for the equipment introduced include: minimum field capacity, minimum field efficiency, fuel consumption, noise, vibration and maximum shrinkage. Data loss yields are taken at each stage: Harvest losses, shrinkage losses, drying losses [6]. Moisture content [6] Estimation of shelf life by the Arhenius method.

\section{Results and Discussion}

\subsection{Corn Potential in North Sulawesi}

In Table 1, land area and corn production in North Sulawesi and 3 study location districts are Minahasa, North Minahasa and South Minahasa with an area of 27,533 Ha or around $34.1 \%$ of the corn land area in North Sulawesi with a total production of 102791 tons $(34.21 \%)$ and only contributes $1.5 \%$ of Indonesia's maize production. Corn ranks third after wheat and rice in cereal production worldwide [45] therefore it is an important crop in terms of food security.

Table 1. Land Area, Production and Productivity of Maize in North Sulawesi Province 2016

\begin{tabular}{|r|l|r|r|r|}
\hline No. & \multicolumn{1}{|c|}{ District/City } & \multicolumn{1}{c|}{$\begin{array}{c}\text { Harvested } \\
\text { Area(Ha) }\end{array}$} & $\begin{array}{c}\text { Production } \\
\text { (ton) }\end{array}$ & $\begin{array}{c}\text { Productivity (quintal/ } \\
\text { ha) }\end{array}$ \\
\hline 1 & Bolaang Mongondow & 38,394 & 140,470 & 36.6 \\
\hline $\mathbf{2}$ & Minahasa & $\mathbf{1 5 , 4 6 3}$ & $\mathbf{5 7 , 0 3 0}$ & $\mathbf{3 6 . 9}$ \\
\hline 3 & Sangihe Islands & 112 & 225 & 38.8 \\
\hline 4 & Talaud Islands & $\mathbf{7 , 3 6 8}$ & $\mathbf{2 8 , 0 1 5}$ & 38.6 \\
\hline $\mathbf{5}$ & South Minahasa & $\mathbf{4 , 7 0 2}$ & $\mathbf{1 7 , 7 4 6}$ & $\mathbf{3 8 . 0}$ \\
\hline $\mathbf{6}$ & North Minahasa & 3,798 & 14,500 & 38.7 \\
\hline 7 & North Bolaang & & & 38.2 \\
& Mongondow & 56 & 215 & 38.4 \\
\hline 8 & Siau, Tagulandang, Biaro & 4,760 & 18,158 & 38.2 \\
\hline 9 & Southeast Minahasa & 285 & 1,101 & 38.6 \\
\hline 10 & South Bolaang & 1,597 & 6,138 & 38.4 \\
\hline & Mongondow & 374 & 1,437 & 38.4 \\
\hline 11 & East Bolaang Mongondow & 428 & 1,646 & 38.5 \\
\hline 12 & Manado & 2,745 & 10,514 & 38.3 \\
\hline 13 & Bitung & 744 & 2,863 & 38.5 \\
\hline 14 & Tomohon & 80,885 & 300,490 & 37.2 \\
\hline 15 & Kotamobago & & & \\
\hline & North Sulawesi & & & \\
\hline
\end{tabular}

Corn contributes to energy consumption per capita and income especially in developing countries. [40] consider it a commercial crop and also a staple food for several countries. Currently, world corn production is around 10.14 billion MT [45]. The United States is the world's leading producer of maize with more than $30 \%$ following China $21 \%$, Brazil $7.9 \%$ and Indonesia is ranked 7th in the world (2017) accounting for around 7\% of the world's overall grain production.

The selling price of corn in North Sulawesi does not use applicable quality standards, causing farmers to not pay attention to the quality of corn produced at harvest. Because corn is one of the food and feed commodities with high levels of aflatoxin contamination, the HACCP approach is needed to control aflatoxin contamination [22]. To produce quality 
corn, it is necessary to know the quality standards issued by the Indonesian National Standard (SNI) for both food and feed. The quality requirements of maize are free from pests and diseases, free of foul odors, acids or other odors, free of chemicals such as insecticides and fungicides, and have normal temperatures.

Corn quality standards according to SNI are divided into four quality classes. Quality I maximum water content is $(14 \%)$ maximum damage is $(2 \%)$, colored items, broken grains and maximum impurities content (1\%) and maximum aflatoxin $(5 \mathrm{mg} / \mathrm{kg})$ [13].

[38] A decrease in grain quality can also occur due to the growth of fungi that can produce aflatoxin in high water content. So that a better drying facility is needed than relying on sun-drying during pre and post harvest. Most grain damage is due to a combination of external functions

\subsection{Equipment Allocation and Tool Perfomance}

Equipment requirements in each region can be calculated based on land area and corn production using the formula UT = Ls-Lg / Cap. By using this formula, the need for tools in each location can be calculated. Minahasa with a production of around 57,030 tons with an allocation of 88 units of corn sheller, each tool only works 76,018 kg / day. Minahasa with 57,030 tons of corn production, only 76 units of corn shellers are needed. Likewise, North Minahasa with a production of 17,746 tons, ideally only needs around 23 units, while South Minahasa with a production of 28,015 tons requires 37 units (Table 2). Thus, there are still many tools that work below the existing capacity. The need for a vertical dryer or flat bed dryer with a dryer capacity of 3-6 tons / day. Therefore, Minahasa requires 26 units, South Minahasa 13 units and North Minahasa 8 units. For more details, see Table 2.

Table 2. Estimated Corn sheller and Vertical Dryer requirements based on corn production

\begin{tabular}{|c|c|c|c|c|c|c|c|}
\hline \multirow[t]{2}{*}{ No } & \multirow{2}{*}{$\begin{array}{l}\text { District } \\
\text { /City }\end{array}$} & \multirow{2}{*}{$\begin{array}{r}\text { Harvested } \\
\text { Area(Ha) }\end{array}$} & \multirow{2}{*}{$\begin{array}{l}\text { Production } \\
\text { (ton) }\end{array}$} & \multicolumn{2}{|c|}{ Existing Tools } & \multicolumn{2}{|c|}{ Requirement } \\
\hline & & & & $\begin{array}{l}\text { Corn } \\
\text { Sheller/ } \\
\text { Corn } \\
\text { Combine } \\
\text { Harvester }\end{array}$ & $\begin{array}{l}\text { Flat } \\
\text { Bed } \\
\text { Dryer/ } \\
\text { Vertical } \\
\text { Dryer }\end{array}$ & $\begin{array}{l}\text { Corn } \\
\text { Sheller/ } \\
\text { Corn } \\
\text { Combine } \\
\text { Harvester }\end{array}$ & $\begin{array}{l}\text { Flat Bed } \\
\text { Dryer/ } \\
\text { Vertical } \\
\text { Dryer }\end{array}$ \\
\hline 1 & Minahasa & 15,463 & 57,030 & 90 & 7 & 76 & 26 \\
\hline 2 & $\begin{array}{l}\text { North } \\
\text { Minahasa }\end{array}$ & 4,702 & 17,746 & 85 & 3 & 23 & 8 \\
\hline 3 & $\begin{array}{l}\text { South } \\
\text { Minahasa }\end{array}$ & 7,368 & 28,015 & 85 & 6 & 37 & 13 \\
\hline
\end{tabular}

In Table 2 it can be seen that the corn sheller is sufficient to even exceed the requirements, while the dryer is only fulfilled around $14 \%$. If yield losses can be reduced by the use of a $1.9 \%$ shell and dryer machine then the additional income obtained from yield losses in the three study areas is 1.2-1.3 billion dollar.

In some areas, sales are made after harvest, this method can harm farmers because the price is low. According to [17] with respect to the law of supply and demand, if demand decreases and supply remains unchanged, it leads to lower prices $[24,14,49,1,36,11,37$, 42]. Price variations encourage farmers to save, $1 \%$ price variation is equivalent to saving $8.4 \mathrm{~kg}$. Therefore, households can increase profits by storing corn until market prices improve [18].

The use of agricultural tools is a must in order to reduce yield losses. Matthews [38] asserts that losses can occur when grain is scattered or leaked, or in the bio-decay process in which the grains become rotten after fungal attack or are physically consumed by pests such as insects, rodents or birds. It involves biotic and abiotic factors which contribute very 
high to the damage to the physical value of corn kernels, resulting in low selling prices. The decline in grain quality can also occur due to the growth of fungi that can produce aflatoxin in high water content. So a better drying facility is needed than relying on sun-drying during pre and post-harvest to achieve the safety of corn kernels. Most of the damage to grain is caused by a combination of various external functions.

\subsection{Postharvest Shrinkage}

Efforts to increase corn production must be in line with post-harvest handling because the rate of yield loss is quite high. According to post-harvest corn handling includes harvesting, shelling, drying, transporting and storing. [34, 43] reported that the shrinkage of corn yield in post-harvest activities (excluding storage) ranged from 1.2 to $5.2 \%$. From the results of the Focus Group Discussion (FGD) and the results of the postharvest handling corn at the farm level can be seen in Table 3 .

Table 3. Existing Post-harvest Technology and Crop Loss (TA. 2017)

\begin{tabular}{|c|c|c|c|}
\hline Description & Existing & Introducing Technology & Yield Loss (\%) \\
\hline Harvest & $\begin{array}{l}\text { Hands, when harvesting } \\
\text { generally sees physically: } \\
\text { corn stalk, brown color, } \\
\text { dry leaves. }\end{array}$ & $\begin{array}{l}\text { Hands, when harvesting } \\
\text { see physically (leaves } \\
\text { have started to dry out, } \\
\text { brown color) and harvest } \\
\text { age according to existing } \\
\text { varieties } 100-120 \text { days }\end{array}$ & $\begin{array}{l}\text { Shattered at harvest } 0.05- \\
0.1 \text { Sheller delay } 0.5-1 \%\end{array}$ \\
\hline Sheller & $\begin{array}{l}\text { Hands Traditional wood } \\
\text { shelled rubber-coated tire }\end{array}$ & Corn sheller & $\begin{array}{l}\text { Scattered, wasted, broken } \\
\text { by tools } 0.5-2 \%\end{array}$ \\
\hline Drying & $\begin{array}{l}\text { Dried by the sun using a } \\
\text { mat } \\
\text { Smoke with coir or } \\
\text { corncobs } 2-3 \text { days } \\
15 \% \text { moisture content }\end{array}$ & $\begin{array}{l}\text { Vertikal dryer Flat bed } \\
\text { Dryer 8-12 hours } \\
11 \% \text { moisture content }\end{array}$ & $\begin{array}{l}\text { Shattered storage time in } \\
\text { sacks eaten by chicken } \\
0.2-0.4\end{array}$ \\
\hline Transportation & $\begin{array}{l}\text { Cow Wheelbarrow } \\
\text { Motorcycle }\end{array}$ & Motorcycle Car & $\begin{array}{l}\text { Scattered because the } \\
\text { packaging leaked } 0.01 \text { - } \\
0.02\end{array}$ \\
\hline Storage & $\begin{array}{l}\text { Shed with mat and use } \\
\text { plastic sacks (cob and } \\
\text { shelled) }\end{array}$ & $\begin{array}{l}\text { Plastic bag } \\
0.08 \mathrm{~mm} \text { polyethylene } \\
\text { plastic } \\
\text { Silo } \\
\end{array}$ & $\begin{array}{l}\text { Scattered while storing } \\
\text { Pest and Disease } \\
0,1-0,2 \%\end{array}$ \\
\hline Packaging & Plastic sacks & Thick plastic sacks & $\begin{array}{l}\text { Scattered when packing } \\
0,05-0,1\end{array}$ \\
\hline Marketing & $\begin{array}{l}\text { Picked up at home by the } \\
\text { traders } \\
\text { KA } 15 \% \text { price IDR } \\
2500 / \mathrm{kg}\end{array}$ & $\begin{array}{l}\text { Picked up at the farmer } \\
\text { with a standard price IDR } \\
3000 / \mathrm{kg} \\
\text { KA. } 13 \% \\
\end{array}$ & \\
\hline Total yield loss & $\begin{array}{l}\text { Overall yield loss } \\
\text { according to farmers } \\
\text { calculations is } 5 \% . \\
\text { Production of } 5 \text { tons / ha } \\
\text { yields a loss of } 250 \mathrm{~kg} \\
\text { (IDR } 625000 / \text { ha) }\end{array}$ & $\begin{array}{l}\text { Estimated decrease of } 1 \% \\
\text { can save products of } 50 \\
\mathrm{~kg} / \text { ha or IDR } 125,000 \text { / } \\
\mathrm{ha}\end{array}$ & $\begin{array}{l}1,92 \% \times 5 \text { ton }(96 \mathrm{~kg} / \mathrm{ha} \\
=\mathrm{IDR} 240.000 / \mathrm{ha})\end{array}$ \\
\hline
\end{tabular}

In Table 3, the highest yield shrinkage occurs in the shelling process that is $0.5-2 \%$. But it is still lower than that reported by Ananto et al [2] which is $4.0 \%$. Overall postharvest losses are $1.92 \%$ lower than the results of the study reported by Director General of Food Crops [19]. Likewise, the quality loss is $2-3 \%$ lower than reported by Aqil [7] which is $4 \%$ 
and Director General of Food Crops [19] is 5-10\%. To get quality corn kernels, the important things to consider in shelling processing are the water content of the seeds, the shape and construction of the tooth of the sheller, the distance of the tooth tip of the sheller and the rotation speed of the cylinder [43].

In general, corn storage at the farmer group level does not meet the quality requirements, besides the water content is still quite high, the storage facilities are inadequate. Storage facilities are needed to maintain the quality of corn kernels and overcome excess production during the main harvest [7].

In Table 3, the yield loss due to storage and packaging is $0.1-, 02 \%$. Loss of yield due to inadequate storage facilities as reported by Singleton [46] stated that the amount of corn kernels lost to storage due to rodents would be sufficient to feed 7 million people for a year at a rate of $0.5 \mathrm{~kg} /$ day / person with a projected value of 141.7 million USD which is 11.1 USD for every $100 \mathrm{~kg}$. The use of triple bags (PICS bags) was reported to reduce grain losses by $90 \%$ [16]. Apart from improved storage facilities, farmers should be well informed about safe moisture levels of grain. Balancing humidity and temperature is key to maintaining grain quality and the best price. So it is highly recommended that after harvest, it is immediately dried at a safer humidity level of $10-13 \%$ for cereals and $7-8 \%$ for oil [50]. Post-harvest losses occur along the value chain, namely harvest handling and storage $(37 \%)$, processing $(7 \%)$, distribution and marketing (13\%), consumption 5\% (Lipinski et al., 2013). In most developing countries, storage pests cause large economic losses [10].

\subsection{Technical Test of Postharvest Equipment at farmers group Level}

The technical test tool which is a help from the Post-harvest Center are the peeled corn sheller, traditional sheller, gas heat source dryer and sun dryer. The calculation results can be seen in Table 4.

Table 4. Observation results on the use of shellers and dryers in North Sulawesi in 2017

\begin{tabular}{|l|c|c|c|c|}
\hline Type of tool & $\begin{array}{c}\text { Labor } \\
\text { (person) }\end{array}$ & $\begin{array}{c}\text { Operating time } \\
\text { (minutes } / \\
\mathbf{1 0 0} \mathbf{~ k g})\end{array}$ & $\begin{array}{c}\text { Save labor } \\
(\mathbf{O H})\end{array}$ & Lost Results \\
\hline $\begin{array}{l}\text { Post-harvest Sheller } \\
\text { Tool }\end{array}$ & 2 & 9,02 minutes & $10 \mathrm{OH}$ & $0,4-0,8 \%$ \\
\hline Peeler Sheller & 2 & 10.25 minutes & $8 \mathrm{OH}$ & $0,5-0,95 \%$ \\
\hline Traditional Sheller & 1 & 130 minutes & - & $0,1-0,2 \%$ \\
\hline Dryer & 2 & 12 hours/3 ton & $6 \mathrm{OH}$ & $0,1-0,2 \%$ \\
\hline Sun Drying & 1 & $3-4$ days & - & $0,1-0,2 \%$ \\
\hline
\end{tabular}

In Table 4 , it can be seen that the use of a sheller can save labor of $11.43 \mathrm{OH}$ for the corn sheller and $11.17 \mathrm{OH}$ for the peeled corn or around IDR 1,143,000 and IDR 1,117,000, when compared to traditional sheller which is IDR 1,354,100.The advantage of a nonpeeled sheller machine tool is more efficient in terms of time, the rate of damage to seeds is low $(<1 \%)$ because the corn grubby can function as a cushion in the shelling process. Its capacity reaches 3.6 tons of shelled / hour for feed and 1 ton of shelled / hour for seeds with a cleanliness level of $99 \%$ [47]. The use of flat bed dryers can save up to IDR 142,000, at a cost of IDR 658,000, when compared to using a sun dryer with a labor cost of IDR 800,000. If corn production is below 3 tons, the use of tools is not recommended because farmers will experience losses with high production costs. This is the reason why farmers do not use dryers if their corn production is small.

Accelerating the drying process without increasing the temperature with a heat pump system is also cheaper to operate than traditional natural gas fueled systems and produces high quality [12]. Furthermore Aulakh [8] concluded that corn cobs with seed moisture 
content of $30-33 \%$ can be dried faster at $50^{\circ} \mathrm{C}$. Choosing a combination of high and low temperature degrees can reduce drying time compared to drying low temperatures. The best combination for drying is at $50{ }^{\circ} \mathrm{C}$ for 20 hours retains $90 \%$ sprouts. This combination saves drying time by about $21 \%$.

The use of dryers should be used in groups to avoid wasting production costs and efficient use of tools. The use of postharvest equipment can reduce the use of labor which can reduce production costs, also reduce yield losses and can improve the quality of dry shelled corn. According to Saenong and Mas'ud, [44] the use of sheller can alleviate and accelerate the shelling process economically and efficiently, with an efficiency level of up to $95 \%$.

\subsection{Corn Storage}

The results of corn storage in the form of seed, corn rice and corn bran can be seen in Figure 1.

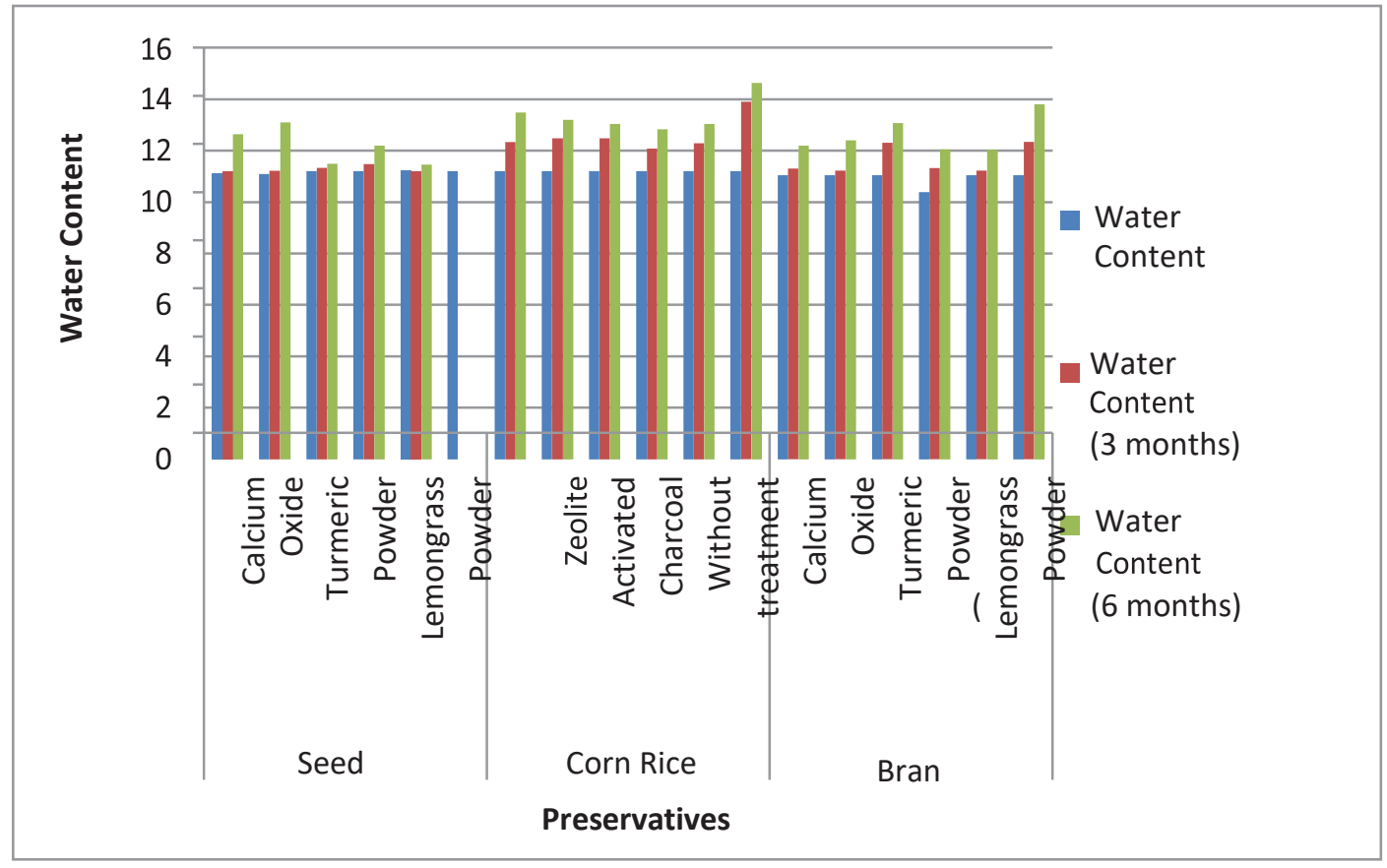

Fig.1. Effect of treatment on water content during storage

Over the last few decades, various synthetic pesticides have been applied to protect stored grain and other agricultural products from insect attack, but their massive use has had so many detrimental effects on the environment and the poisoning of non-target organisms Dhaliwal and Gurdeep. However, these chemicals are declared to be ecologically unsafe because they last longer in the environment and enter the food chain. It has been reported [31], that certain insect pests have acquired resistance to most insecticides. To overcome the bad effects of synthetic pesticides, the best alternative is to use local natural ingredients. Based on some literature and farmer information, in this study several natural ingredients that contain polyphenols are used which can repel pests and maintain moisture content because they are applied in powder and particle form [47].

In Figure 1, it can be seen that the water content increases with the length of storage time. Storage at 3 months has not shown a significant effect on water content. At 6 months 
of storage, there was a significant increase in water content. This is thought to be due to the unstable heat of the storage room which causes humidity, so that water vapor is absorbed into the stored material. Storage of corn grains in closed areas leads to the formation of carbon dioxide and reduction of oxygen, due to permanent respiration. Grains are hygroscopic, they absorb and emit moisture, so they have a significant effect on grain quality and storage capacity which can increase the moisture content of the grains. To avoid this reduction in grain moisture content and storage stability is provided at $12 \%$ humidity. $[3,4,29,5]$.

Reported by Kokom [32] periodic monitoring is carried out to determine temperature fluctuations, gas composition between grains, insect infestations, and grain quality parameters. Environmental temperature has been shown to create a temperature gradient in the upper layer and migration of moisture occurs towards the peak of grain bulk. The moisture content of corn kernels stored in airtight plastic bags remained practically the same during storage, compared to levels in polypropylene packaging. Polypropylene can be used for storing corn, protecting it from insect attack without the need to use insecticides [33]. However, for all treatments, Sitophilus Spp pest was not found. Saenong and Mas'ud [44] reported that at $12 \%$ water content of seeds can inhibit the development of powder beetles. The development of powder beetle population will develop at water levels above $12 \%$ and will develop rapidly at $15 \%$ or more. The safe water content for storing shelled corn is below $14 \%$. At these water levels, mold is difficult to grow and does not cause spores. Under closed storage conditions, insects and fungi combine the power to deplete oxygen from airtight stored corn to create an atmosphere unfavorable for their own survival. Corn grain moisture content is considered safe at $12 \%$ during storage. , attributed to insects not being able to develop properly [25]. It has been reported by Basavaraja [9] in India - Karnataka that the losses due to traditional drying are assessed to be $0.80 \mathrm{~kg} / 0.1$ tonnes of rice and $0.66 \mathrm{~kg} / 0.1$ tonnes of wheat

The use of absorbent materials such as calcium oxide, activated charcoal and zeolite can absorb excessive water content so that it does not change the water content in the stored material. Citronella powder and turmeric containing essential oils and polyphenol components that can inhibit the growth of pests as well as function as absorbents because it is applied in powder form. During storage, warehouse pests that often damage corn are $S$. Zeamais. Some research found that the weight of corn kernels stored for 6 months has decreased by $17 \%$ and the level of damage has reached $85 \%$ due to S. Zeamais attacks [44].The same thing was reported by FAO [23] as the yield loss reached $9.6-20.2 \%$.

The decrease in weight of corn kernels due to pests is very drastic. According to Saenong and Mas'ud [44] S. Zeamays pests can be controlled by using plant-based substances such as A. Nandus lemongrass but their effectiveness as a pesticide is relatively short. Fragrant root and lemongrass with a dose of 5-20\% can suppress the population of the pest powder Sitpphilus spp on corn seeds for 9 weeks, also can reduce the weight loss of seeds and but does not affect the ability to grow. During storage other than Sitophilus zeamais, pests that often attack grain are Rhyzopertha dominica and Tribolium castaneum [20]. It was also reported by that the application of black pepper to corn kernels $(1 \mathrm{~g} / 100$ seeds) was effective in controlling S. Zeamais with a mortality rate reaching $80 \%$.

\section{Conclusion}

Each post-harvest handling stage loses varying results. The loss of conventional methods is around 5\%, introduction technology (Technological Innovation) is around $1.92 \%$. The use of sheller and dryer can save labor $20-50 \%$ compared with manual sheller and sun dryer it also can reduce yield losses of $1.9 \%-3 \%$. Dry shelled corn, corn rice and corn bran stored for 3 months have not experienced significant changes in water content either in control 
(without treatment) or the use of zeolites, activated charcoal, calcium oxide, turmeric powder and lemongrass powder. Up until 6 months of storage, Sitophilus Zeamais has not been found.

\section{References}

1. Abdulai A. Spatial and Vertical price transmission in food staples market chains in Eastern and Southern Africa: Paper Presented at the FAO Trade and Markets Division Workshop on Staple Food Trade and Market Policy, Rome, March 1-2, (2007)

2. Ananto, Handaka and Setyono. Mechanization in the perspective of agricultural modernization, in the Indonesian Rice Economics. Agricultural Research and Development. Jakarta (2004)

3. Angelovič M. , S. Fiantoková, M. Angelovič, Scientific papers Animal Science and Biotechnologies, 46 (2): 431-436 (2013)

4. Angelovič, M., J. Jobbágy, P. Findura, S. Fiantoková, Savremena poljoprivredna tehnika, 41 (1): 1-8 (2015)

5. Angelovič,M., P. Findura, S. Fiantoková, A. Krakowiak, U. Ziemanczyk, K. Rutkowski, Komunální technika. 8: 20-26 (2014)

6. AOAC.1990. assoc. Offic.Anal.Chem. WasingtonDC.

7. Aqil M. Development of Methodology for Emphasis on Shrinkage Results in Corn Shredding Process. Cereals Plant Research Institute. South Sulawesi Proceedings of the National Cereals Week ISBN: 978-979-8940-29-3 (2010)

8. Aulakh J, Regmi A. Post-harvest food losses estimation development of consistent methodology. Scientific Review Committee of the Food and Agricultural Organization of the UN, 2050:1-34 (2013).

9. Basavaraja H, Mahajanashetti SB, Udagatti NC. Economic Analysis of Post-harvest Losses in Food Grains in India : A Case Study of Karnataka. Agricultural Economics Research Review 20(June):117-126 (2007)

10. Boxall RA. Damage and loss caused by the Larger Grain Borer Prostephanus truncatus. Integrated Pest Management Reviews 7(2):105-121 (2002). https://doi.org/10.1023/A:1026397115946

11. Burke WJ. Maize production in Zambia and regional marketing: input productivity and output price transmission. Michigan State University. Agricultural, Food and Resource Economics. (2012).

12. Burris JF, Papademetriou V, Wallin JD, et al. Therapeutic adherence in the elderly: transdermal clonidine compared to oral verapamil for hypertension: Am $\mathrm{J}$ Med; 91 Suppl 1A: 22S-28S. (1991)

13. BSN. Indonesian National Standards. Jakarta (2013)

14. Chirwa EW. Food marketing reforms and integration of maize and rice markets in Malawi. Chancellor College Department of Economics Working Paper WC/05/99. University of Malawi, Zomba, Malawi (1999)

15. Cristopher Mutungi dan Adebayo Abass. Physical Quality of Maize grain harvested and stored by smallholder farmers in the Northern highlands of Tanzania: Effects of harvesting and pre-storage handling pertices in two marginally contrastong agrolocation. J. of Stored Products Research, Volume 84, Desenber 101517 (2019)

16. Daminger A, Datta S, Guichon D. Reducing Post-Harvest Loss - A behavioral Approach, 15 Retrieved from 
http://www.ideas42.org/wpcontent/uploads/2016/10/PostHarvestLoss\%7B_\%7DFINA L.pdf (2016)

17. De Groote H, Kimenju SC, Likhayo P, Kanampiu F, Tefera T, Hellin J. Effectiveness of hermetic systems in controlling maize storage pests in Kenya. Journal of Stored Products Research 53:2736. https://doi.org/10.1016/j.jspr.2013.01.001 Dhaliwal R, Gurdeep S. Traditional food grain storage practices of Punjab. Indian J Traditional Knowledge. 2010; 9(3):526-530. (2013).

18. Didier K, Ricker-Gilbert J, Alexander C, Tahirou A. Effects of Storage Losses and Grain Management Practices on Storage: Evidence from Maize Production in Benin. pp. 1-37. https://doi.org/10.1017/CBO9781107415324.004 (2013)

19. Director General of Food Crops. Hybrid Maize Development Movement. GP-PTT Corn Technical Guidelines. litbang.pertanian.go.id (2016)

20. Dowell FE, Dowell CN. Reducing grain storage losses in developing countries. Quality Assurance and Safety of Crops and Foods 9(1):93-100 (2017). https://doi.org/10.3920/QAS2016.0897

21. Ennis AWB, Dowler WM, Klassen W, Science S, Series N, May FI. Crop Protection to Increase Food Supplies 188(4188):593- 598. http://www.jstor.org/stable/1740170 Accessed: Food and Agriculture (2016).

22. Fitriati, D., Rokhani Hasbullah1, Ridwan Rachmat. Determination of Priority of Postharvest Corn Means to Reduce Loss of Results with Analytical Hierarchy Process (AHP) Method. Journal of Postharvest Agriculture Research | Volume 12 No.2 September: 10-19 (2015)

23. Food and Agriculture Organization (FAO). The state of food and agriculture: Livestock in balance. Food and Agriculture Organisation of the United Nations, Rome (2009). https://doi.org/10.1016/S0140- 6736(75)92740-3

24. Goletti F, Babu S. Market liberalization and integration of maize market in Malawi.pdf. Agricultural Economics 5150(94): 311-324 (1994)

25. Harris KL, Lindbald CJ. Postharvest Grain Loss Assessment Methods pp. 7-158 (1977).

26. Hodges R, Bernard M, Felix R. APHLIS - Postharvest cereal losses in Sub-Saharan Africa, their estimation, assessment and reduction. (2014). https://doi.org/10.2788/19582.

27. O. Daniel, K. O. Oyekale, M. O. Ajala, L. O. Sanni, M. A. Okelana, J. A. Adetumbi, A. C. Akintobi, A. Adebisi, Research Journal of Seed Science, 5 (1): 32-37 (2012)

28. J.R. Mendoza, L. Sabillon, Martinez, C. Campabadal, H.E. Hallen-Adams, A. Bianchini. Traditional maize post-harvest management practicesamongst smallholder farmers in Guatemala. J. Stored Prod. Res., 71, pp 14-21(2017).

29. Jech, J. Et al., Research of the effects of technical and technological conditions on efficiency of post-harvest treatment lines for cereals KSVS. Nitra: SUA, 140 p (2002)

30. Kaaya AN, Warren HL, Kyamanywa S, Kyamuhangire W. The effect of delayed harvest on moisture content, insect damage, moulds and aflatoxin contamination of maize in Mayuge district of Uganda. Journal of the Science of food and Agriculture 85(15):2595-2599. (2005). https://doi.org/10.1002/jsfa.2313

31. Kausarmalik, Rizwana Riasat. Study of combined effect of locally isolated Bacillus thuringiensis and turmeric powder on red flour beetle (Tribalism castaneum). Int $\mathrm{J}$ Curr Microbiol App Sci. 3(4):760-773. (2014)

32. Kukom Edoh ,Ognakossan Agbéko,Kodjo Tounou, Yendouban Lamboni, Kerstin 
Hell. Post-harvest insect infestation in maize grain stored in woven polypropylene and in hermetic bags. International Journal of Tropical Insect Science March, pp. 71-81 (2013). https://doi.org/10.1017/S1742758412000458.

33. Lamboni, Y. and Hell, K. Propagation of mycotoxigenic fungi in maize stores by postharvest insects. International Journal of Tropical Insect Science 29, 31-39. (2009)

34. Lipinski B, Hanson C, Lomax J. Reducing Food Loss and Waste. Creating a Sustainable Food Future, June, pp. 1-40 (2013). https://doi.org/10.2499/9780896295827_03

35. Majumder S, Bala BK, Arshad FM, Haque MA, Hossain MA. Food security through increasing technical efficiency and reducing postharvest losses of rice production systems in Bangladesh. Food Security 8(2):361-374 (2016). https://doi.org/10.1007/s12571-016-0558-x

36. Myers RJ. Evaluating the effectiveness of inter-regional trade and storage in Malawiees private sector maize markets. Food Policy, 41: 75-84 (2013). https://doi.org/10.1016/j.foodpol.2013.04.007

37. Mason NM, Jayne TS, Myers RJ. Smallholder behavioral responses to marketing board activities in a dual channel marketing system: the case of maize in Zambia. International Association of Agricultural Economists Triennial Conference, Foz do Iguaçu, Brazil (pp. 18https://www.researchgate.net/profile/Nicole_Mason2/publication/254387555_Smallho 1der_Behavioral_Responses_to_Marketing_Board_Activities_in_a_Dual_Channel_Ma rketing_System_The_Case_of_Maize in_Zambia/links/02e7e53ac8b9429e31000000.pdf (2012)

38. Matthews G. Integrated vector management: A new concept. International Pest Control 48(5): 241-242 (2006). https://doi.org/10.1564/v24

39. Ministry of Agriculture. Corn Harvesting and Postharvest Processing. Agricultural Human Resource Education and Development Agency (2015)

40. Muir JF, Pretty J, Robinson S, Thomas SM, Toulmin C. Food Security: The Challenge of Feeding 9 Billion People. Science, 327(5967):812-818 (2010)

41. Munarso, S. J. and Ridwan Thahir. Post-harvest corn technology at the farm level and the feasibility of the corn starch industry. Indonesian Corn Economy. Agricultural Research and Development Agency. Agriculture Department. (2005)

42. Ricker-gilbert J, Mason NM, Darko FA, Tembo ST. What are the effects of input subsidy programs on maize prices? Evidence from Malawi and Zambia. Agricultural Economics 44(2013):671-686. (2013) https://doi.org/10.1111/agec.12081

43. Rudy C. Corn Sheller Tool with Klobot. 400 Innovative Agricultural Balitbang Technology. Center for Agricultural Mechanization Development. Serpong. (2014)

44. Saenong and Mas'ud. Performance of the Technology of Powder Beetle Pest Management in Corn and Sorghum Plants. Proceedings of the National Cereals Seminar ISBN: 978- 979-8940-27-9 410. Research Institute for Cereals (2009)

45. Suleiman RA, Rosentrater KA. Current Maize Production, Postharvest Losses and the Risk of Mycotoxins Contamination in Tanzania. ASABE International Meeting. American Society of Agricultural and Biological Engineers (2015) https://doi.org/10.13031/aim.20152189434

46. Singleton GR, Hinds LA, Krebs CJ, Spratt DM. Rats, mice and people: rodent biology and management. January, 548.

https://www.researchgate.net/profile/Grant_Singleton/publication/272887645 
47. Tandiabang, J.A. Tenriawe, and Surtikanti. Corn Postharvest Pest Management. Cereals Plant Research Institute. Maros (2015) http: balitsereal litbang.pertanian.go.id

48. Taylor P, Mdangi M, Mulungu LS, Massawe AW, Eiseb SJ, Tutjavi V, Kirsten F. International Journal of Pest Management Assessment of rodent damage to stored maize (Zea mays L) on smallholder farms in Tanzania. International Journal of Pest Management 59(1):55-62 (2012)

49. Tostao E, Chung C, Brorsen BW. Integrating the Structural Auction Approach and Traditional Measures of Market Power, February, 1-36. (2006) http://ideas.repec.org/p/ags/aaea06/21244.html

50. Waliyar F, Umeh VC, Traore A, Osiru M, Ntare BR, Diarra B, Sudini H . Prevalence and distribution of a flatoxin contamination in groundnut Arachis hypogaea L. in Mali, $\begin{array}{lllll}\text { West Africa. } & \text { Crop } & \text { 70:1-7. } & \text { (2015). }\end{array}$ https://doi.org/10.1016/j.cropro.2014.12.007.

51. Zhang Q, Muir WE, Sinha RN, Cenkowski S. Heat production in wet wheat under adiabatic conditions. Canadian agricultural engineering, 34(3):233-238. (1992). 